\title{
Monitoring calculation of closure change of Extradosed Cable-stayed Bridge
}

\author{
Jing Xian SHI ${ }^{1}$, Zhi Hong RAN ${ }^{2}$ \\ ${ }^{1}$ Oxbridge College, Kunming University of Science and Technology,KunMing 650106 Yunnan, China; \\ ${ }^{2}$ School of Architecture and Urban Planning. Yunnan University, Kunming 650091, Yunnan, China
}

\begin{abstract}
During the construction of extradosed cable-stayed bridge in Yunnan province, China, the construction unit has made certain changes in the construction process of the closure section due to environmental restrictions: remove the hanging basket after the closure, the sling shall not be provided in closure section, the function of the sling is realized by the hanging basket on the 16th beam. In case of this change, the bridge has been constructed to section 15 th. In order to ensure the smooth and orderly progress of each stage in the closure phase, this article is arranged according to the construction plan, appropriate adjustment of related procedures, checking the bridge safety at all stages of construction, the stress and force of the main girder are compared to ensure the safety of the construction after closure changes. Adjust the height of the beam of the 16th and 17th to adapt the new construction plan, and the bridge closure smoothly.
\end{abstract}

\section{Engineering Overview}

The bridge analyzed in this paper is located in Yunnan province in China, main spans of extradosed cable-stayed bridge is $2 * 85 \mathrm{~m}$, bridge width is $27 \mathrm{~m}$; the grade of Urban trunk road is $\amalg$, the motor vehicle is two-way and four-lane; the design speed is $30 \mathrm{~km} / \mathrm{h}$; design load for highway is levelII, the throng is $3.5 \mathrm{kN} / \mathrm{m}^{2}$; design useful life of 100 years. The design elevation of the bridge is

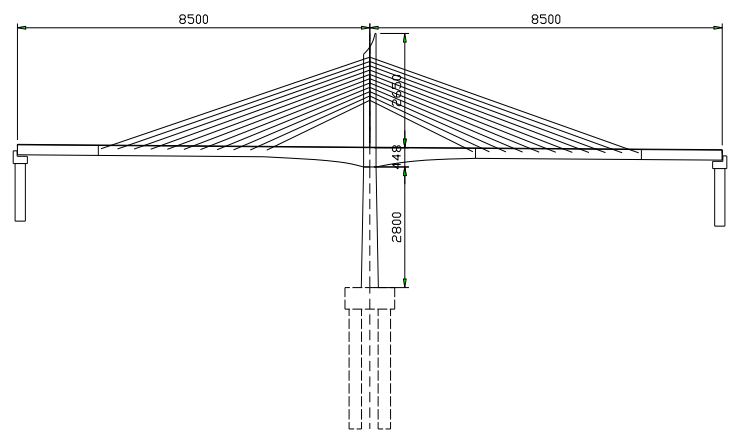

Figure 1 Main Bridge Elevation Layout/ cm

\subsection{9-451.389m.}

The facade layout of the main bridge is shown in figure1, and the structure of the cable-stayed bridge is adopted. The main beam adopts single box three-compartment large cantilever variable cross-section PC continuous box beam (shown in figure2), the main pier is thin wall type pier, high $28 \mathrm{~m}$, and the deck thickness is $5 \mathrm{~m}$. The pier beam adopts the consolidation form. The bridge model material is summarized in table 1.

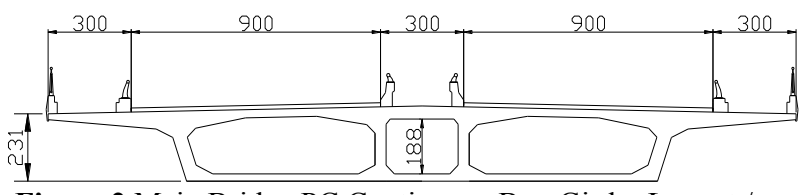

Figure 2 Main Bridge PC Continuous Box Girder Layout /cm

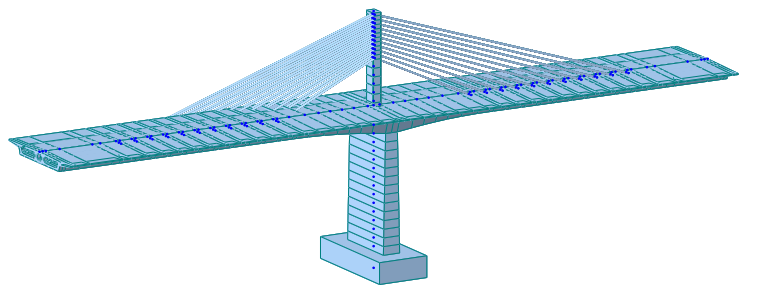

Figure 3 The overall calculation model of structure

Table 1 Material parameters Summary of calculation model

\begin{tabular}{|c|c|c|c|c|c|}
\hline $\begin{array}{l}\text { Material } \\
\text { code }\end{array}$ & Unit type & Material type & $\begin{array}{l}\text { Elastic } \\
\text { Modulus } \\
(\mathrm{MPa})\end{array}$ & $\begin{array}{l}\text { Volumetric } \\
\text { weight } \\
(\mathrm{kN} / \mathrm{m} 3)\end{array}$ & $\begin{array}{c}\text { Coefficient of } \\
\text { thermal expansion } \\
\left(1 /{ }^{\circ} \mathrm{C}\right)\end{array}$ \\
\hline
\end{tabular}

\footnotetext{
* Corresponding author: sara_shivip@163.com; 1973941@qq.com
} 


\begin{tabular}{cccccc}
\hline 1 & $\begin{array}{c}\text { Bridge pier, main beam, } \\
\text { main tower }\end{array}$ & $\begin{array}{c}\text { Concrete50 } \\
\text { High strength } \\
\text { steel wire }\end{array}$ & $3.45 \mathrm{E}+04$ & 26 & $1.00 \mathrm{E}-05$ \\
2 & Stay Cables & $\begin{array}{c}\text { High strength } \\
\text { steel wire }\end{array}$ & $1.95 \mathrm{E}+05$ & 78.5 & $1.20 \mathrm{E}-05$ \\
3 & Prestressed & sto5 & 78.5 & $1.20 \mathrm{E}-05$ \\
\hline
\end{tabular}

This monitoring calculation adopts the MIDAS Civil8.32 analysis program. The structure of the structure is analyzed by the structure of the space bar system. The structure consists of bridge pier, main beam, main tower and lasso. The structural analysis model is shown in figure 3. The total bridge has 146 units and 172 nodes. The boundary conditions in the analysis are: the bottom end consolidation of the cable tower, the transition pier and the auxiliary pier are simulated by the movable hinge support, and the lower end of the cast-in-place bracket is fixed hinge support.

\section{Construction change requirement}

diagram in the original bridge design document, the cantilever of closure strap and its formwork system are 32 tons heavy, remove the hanging basket before closure stage, at the end of the closure, the weight is 58tons. But the construction unit proposed: remove the hanging basket after the closure, the sling shall not be provided in closure section, the function of the sling is realized by the hanging basket on the 16th beam, that meansthe former lifting point is located on the 17 th beam segment and is $58 \mathrm{~cm}$ from the starting point, to realize the function of the dragon sling (number of beam segment is shown in Figure 4). The concrete wet weight of all the hedrons is borne by the cantilever end, so the closure weight is increased from 58 to 105 tons.

According to the requirements of construction sequence

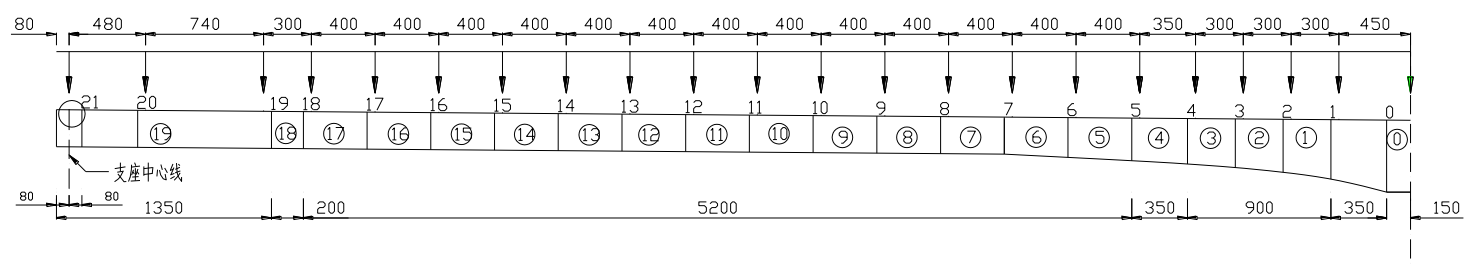

Figure 4 Diagram of the main beam section numbers

When this change is proposed, the bridge has been constructed to 15 th beam segment, in order to ensure the successful completion of the sub stages in the closure section, the relevant procedures are adjusted properly in accordance with the construction plan. The hanging basket shall not be removed until it is closed and only moved forward; the weight of the cantilever end is 105tons; after repeated trial calculation, in order to make the bridge state as consistent as possible with the original design, it is necessary to adjust the single tension of 11 th cable to 415tons, and make two adjustments after the completion of the bridge, reduce the single tension of 11 th cable to 395 tons. The closure conditions of the two models are shown in table 2 .

Table 2 Comparison table of condition adjustment

\begin{tabular}{|c|c|c|}
\hline $\begin{array}{c}\text { Name of } \\
\text { construction } \\
\text { component }\end{array}$ & Description of the original model & Described conditions of the adjustment model \\
\hline $\begin{array}{l}\text { 16th section of } \\
\text { Beam }\end{array}$ & Tension cable-stayed & Cable Tension of 11 th adjustment to $415 \mathrm{t}$ \\
\hline $\begin{array}{l}\text { 17th section of } \\
\text { Beam }\end{array}$ & \multicolumn{2}{|c|}{ Move forward Hanging basket、Pouring concrete、Tensioning prestress } \\
\hline Side-span & \multicolumn{2}{|c|}{ With full framing construction } \\
\hline \multirow{4}{*}{ Closure Section } & $\begin{array}{l}\text { Tear down hanging basket、Put } 32 \mathrm{t} \text { in } \\
\text { final closure at both ends of the } \\
\text { closure }\end{array}$ & $\begin{array}{l}\text { Move forward Hanging basket (The front hanging } \\
\text { point is located on the } 17 \text { th beam section and } \\
\text { from the starting point of } 0.58 \mathrm{~m} \text { ) }\end{array}$ \\
\hline & Pressure $58 \mathrm{t}$ in the end of the closure & Pressure $105 t$ in the end of the closure \\
\hline & \multicolumn{2}{|c|}{$\begin{array}{l}\text { Installation of closure and steel skeleton、Unloading and pouring concrete、Waiting for age } \\
\text { then tensioning prestress }\end{array}$} \\
\hline & Tear down Hanger & Tear down hanging basket \\
\hline \multirow[t]{3}{*}{ Side-span } & \multicolumn{2}{|c|}{ Tear down full framing } \\
\hline & Stage II load & $\begin{array}{l}\text { Stage II load, The second adjustment of } 11 \text { th } \\
\text { cable tension to } 385 \mathrm{t}\end{array}$ \\
\hline & \multicolumn{2}{|c|}{ Into the bridge conditions } \\
\hline
\end{tabular}




\section{Safety checking calculation in construction stage}

The stress calculation results of the main girder in each construction stage are shown in figure5 and 6.It can be seen from the picture, the stress change is small compared with the original model and the adjusted model, but they are all within safe limits. The results of pier strength calculation are shown in table 3 . As you can see from the table, the capacity of the maximum cantilever stage (cast concrete in the concrete) meets the requirements.
《
Guidelines
for

Design of Highway Cable-Stayed Bridge $\gg \quad$ (JTG/T D65-1-2007) Specification 3.4.2 stipulate: Under construction the safety factor of the cable-stayed cable should greater than 2.0. The calculations results of the force of the bridge are shown in table 4 , it can be seen from the table that all the forces of the cable meet the standard requirements.

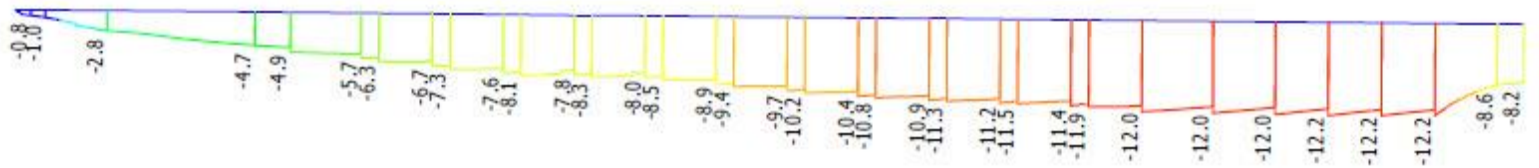

(a) Compressive stress envelope of the upper edge of the main beam

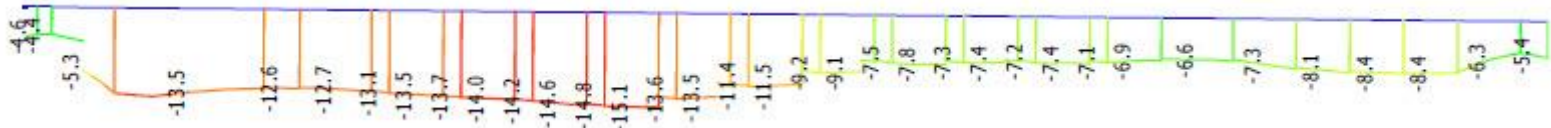

(b) Compressive stress envelope of the lower edge of the main beam

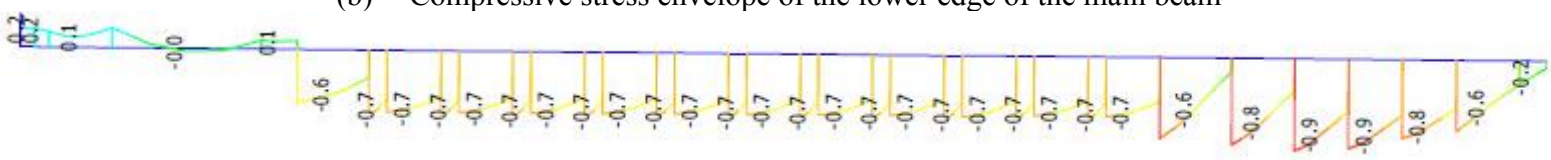

(c) Compressive stress envelope of the lower edge of the main beam

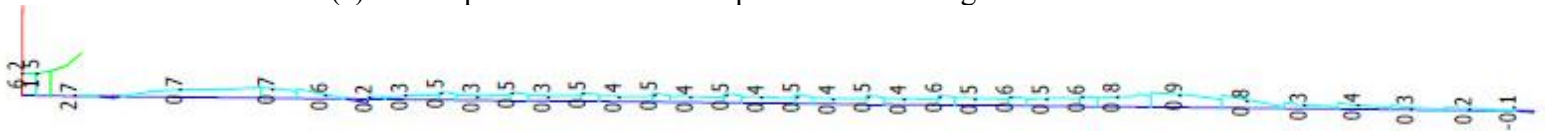

(d) Tensile stress envelope of the lower edge of the main beam

Figure 5 Calculation results of main beam stress in construction stage the original model / MPa

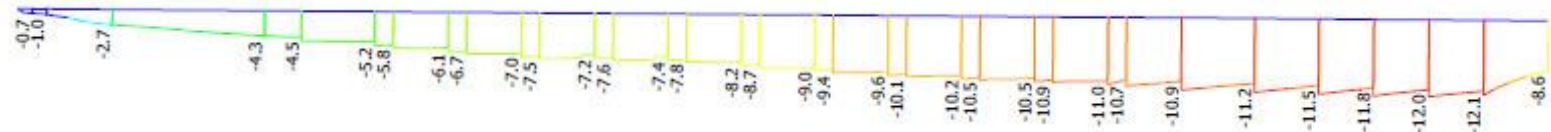

(a) Compressive stress envelope of the upper edge of the main beam

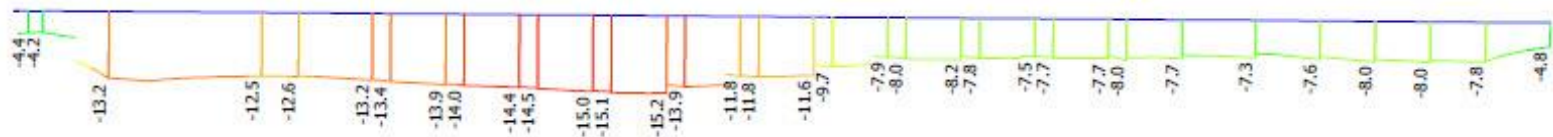

(b) Compressive stress envelope of the lower edge of the main beam

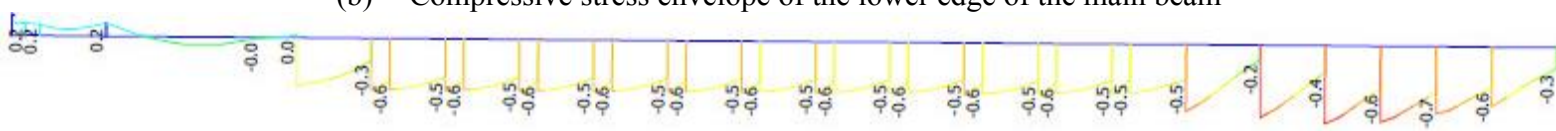

(c) Compressive stress envelope of the lower edge of the main beam

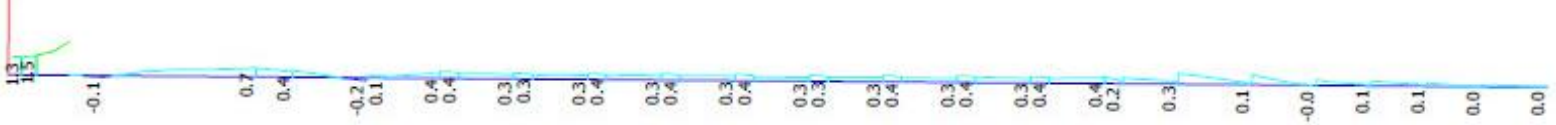

(d) Tensile stress envelope of the lower edge of the main beam

Figure 6 Calculation results of main beam stress in construction stage the adjusted model / MPa

Table 3 Calculation Results of Bridge pier and tower Strength in Construction Stage

\begin{tabular}{cccc}
\hline & Load Conditions & $\begin{array}{c}\text { Largest Cantilever Stage (Original } \\
\text { model) }\end{array}$ & $\begin{array}{c}\text { Largest Cantilever Stage (Adjusted } \\
\text { model) }\end{array}$ \\
\hline \multirow{3}{*}{ Pounding } & Axial Force/kN & -130460 & -132177 \\
Bottom & Forward Bending & 522 & 536 \\
Section & Moment $/ \mathrm{kN} . \mathrm{m}$ & 1480000 & 1450000 \\
& Section Resistance/kN & 11.65 & 10.97 \\
\hline
\end{tabular}




\begin{tabular}{cccc}
\hline & Axial Force/kN & -55713 & -57407 \\
The & Forward Bending & 421 & 434 \\
Tower & Moment/kN.m & 143000 & 141000 \\
Bottom & Section Resistance/kN & 2.6 & 2.45 \\
Section & Safety coefficient & & \\
& & & \\
\hline
\end{tabular}

Table 4 The maximum cable force calculation results in the construction stage

\begin{tabular}{ccccccccc}
\hline \multirow{2}{*}{$\begin{array}{c}\text { Serial } \\
\text { number }\end{array}$} & \multicolumn{3}{c}{ The original model/kN } & \multicolumn{3}{c}{ The adjusted model/kN } & \multicolumn{2}{c}{ Safe coefficient } \\
\cline { 2 - 8 } & $\begin{array}{c}\text { Main } \\
\text { beam } \\
\text { side }\end{array}$ & $\begin{array}{c}\text { Bridge } \\
\text { tower } \\
\text { side }\end{array}$ & $\begin{array}{c}\text { Average } \\
\text { value }\end{array}$ & $\begin{array}{c}\text { Main } \\
\text { beam } \\
\text { side }\end{array}$ & $\begin{array}{c}\text { Bridge } \\
\text { tower } \\
\text { side }\end{array}$ & $\begin{array}{c}\text { Average } \\
\text { value }\end{array}$ & $\begin{array}{c}\text { The } \\
\text { original } \\
\text { model }\end{array}$ & $\begin{array}{c}\text { The adjusted } \\
\text { model }\end{array}$ \\
\hline 1 & 3266 & 3270 & 3268 & 3266 & 3270 & 3268 & 2.47 & 2.47 \\
2 & 3283 & 3287 & 3285 & 3283 & 3287 & 3285 & 2.46 & 2.46 \\
3 & 3317 & 3321 & 3319 & 3317 & 3321 & 3319 & 2.43 & 2.43 \\
4 & 3614 & 3620 & 3617 & 3614 & 3620 & 3617 & 2.45 & 2.45 \\
5 & 3648 & 3654 & 3651 & 3648 & 3654 & 3651 & 2.43 & 2.43 \\
6 & 3680 & 3686 & 3683 & 3680 & 3686 & 3683 & 2.4 & 2.4 \\
7 & 3980 & 3987 & 3984 & 3980 & 3987 & 3984 & 2.42 & 2.42 \\
8 & 4006 & 4013 & 4010 & 4006 & 4013 & 4010 & 2.4 & 2.4 \\
9 & 4028 & 4036 & 4032 & 4028 & 4036 & 4032 & 2.39 & 2.39 \\
10 & 4047 & 4055 & 4051 & 4047 & 4055 & 4051 & 2.38 & 2.38 \\
11 & 4062 & 4071 & 4067 & 4720 & 4729 & 4724 & 2.37 & 2.04 \\
\hline
\end{tabular}

the modified model is beneficial to the structure. Table5

\section{The comparison of stress of the main beam and the cable force}

The upper margin and lower edge stress of the original model and the adjusted model are shown in figure 7 and 8. It can be seen from the picture, the maximum value of upper margin compressive stress is $0.3 \mathrm{MPa}$, the lower margin stress difference is $0.8 \mathrm{MPa}$. The lower edge of the bridge produces tensile stress due to the automobile live load, therefore; the $0.8 \mathrm{MPa}$ compressive stress of is a comparison of the calculation results for the bridge stage. The maximum difference was $2.4 \%$ after adjustment of cable force. Table 8.10.4-1 in Terms 8.10.4 of 《Standard for quality inspection and assessment of highway engineering》(JTG F80/1-2004) stipulate: The measured force and the design of the force extreme error are $10 \%$, therefore, the original model and adjusted model of the force difference of $2.4 \%$ can not affect the load-carrying capacity of the bridge.

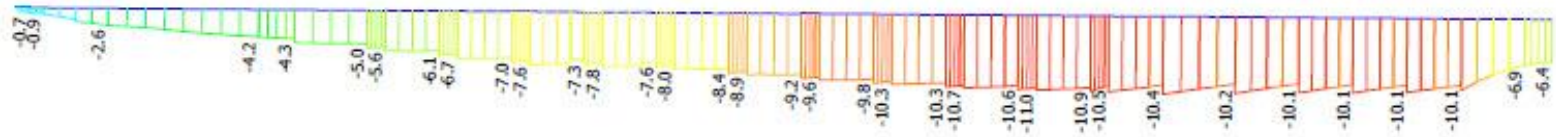

(a) The stress value of the upper edge

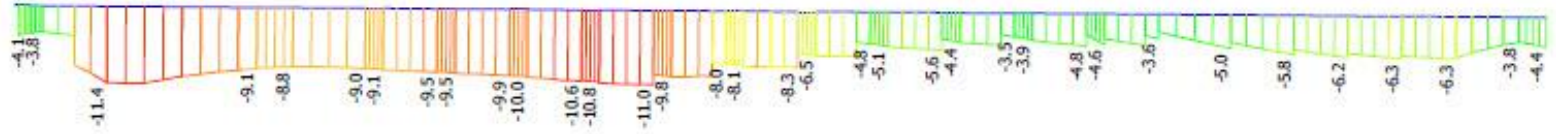

(b) The stress value of the lower edge

Figure 7 The stress map of the original model when end of construction/MPa

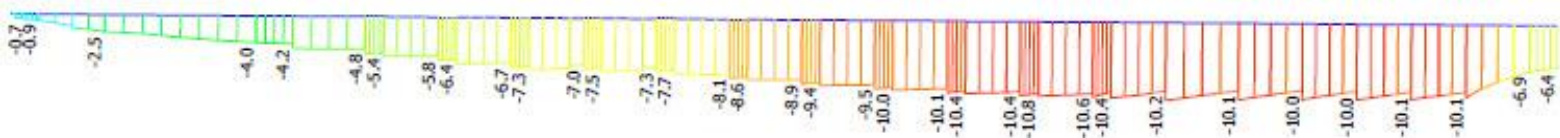

(a) The stress value of the upper edge

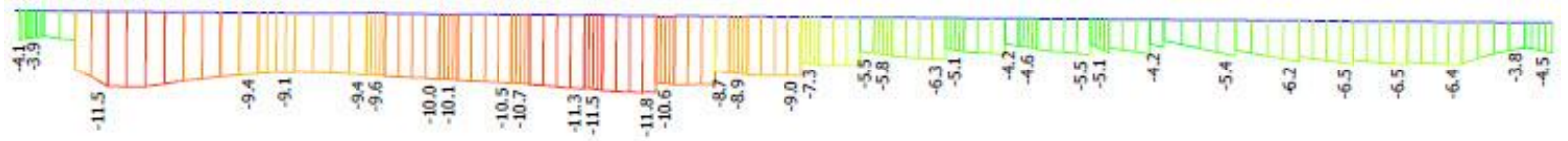

(b) The stress value of the lower edge

Figure 8 The stress map of the adjusted model when end of construction /MPa

Table 5 The calculation results of cable force in the end of the construction stage

\begin{tabular}{|c|c|c|c|c|c|c|c|c|}
\hline Serial & Main & Bridge & Average & Main & Bridge & Average & The difference of cable & Relative \\
\hline
\end{tabular}




\begin{tabular}{|c|c|c|c|c|c|c|c|c|}
\hline number & $\begin{array}{l}\text { beam } \\
\text { side }\end{array}$ & $\begin{array}{c}\text { tower } \\
\text { side }\end{array}$ & value & $\begin{array}{l}\text { beam } \\
\text { side }\end{array}$ & $\begin{array}{c}\text { tower } \\
\text { side }\end{array}$ & value & $\begin{array}{c}\text { force between original } \\
\text { and adjustment } \\
\text { model } / \mathrm{kN}\end{array}$ & difference $(\%)$ \\
\hline 1 & 2624 & 2628 & 2626 & 2637 & 2642 & 2640 & 14 & 0.5 \\
\hline 2 & 2658 & 2663 & 2660 & 2677 & 2682 & 2680 & 19 & 0.7 \\
\hline 3 & 2699 & 2704 & 2702 & 2725 & 2729 & 2727 & 25 & 0.9 \\
\hline 4 & 2965 & 2971 & 2968 & 3000 & 3005 & 3003 & 35 & 1.2 \\
\hline 5 & 3028 & 3034 & 3031 & 3070 & 3076 & 3073 & 42 & 1.4 \\
\hline 6 & 3092 & 3099 & 3095 & 3142 & 3148 & 3145 & 49 & 1.6 \\
\hline 7 & 3415 & 3422 & 3418 & 3477 & 3484 & 3481 & 62 & 1.8 \\
\hline 8 & 3522 & 3530 & 3526 & 3593 & 3601 & 3597 & 71 & 2 \\
\hline 9 & 3631 & 3639 & 3635 & 3710 & 3718 & 3714 & 80 & 2.2 \\
\hline 10 & 3735 & 3743 & 3739 & 3823 & 3831 & 3827 & 88 & 2.4 \\
\hline 11 & 3834 & 3843 & 3838 & 3915 & 3924 & 3920 & 81 & 2.1 \\
\hline
\end{tabular}

following are dealt with:

\section{Adjustments Calculate of shuttering elevation}

Due to the change of construction sequence and plan, the height of the bridge cannot reach the design value under the completed shuttering elevation. Detailed calculations revealed that the maximum difference between the predicted primary bridge and the original design is $17.5 \mathrm{~mm}$. Therefore, the beam 16th and 17 th sections should be adjusted, and found by the adjusted model, the folding angle of the $17.5 \mathrm{~mm}$ is generated on the beam 15th-16th section. To mitigate this situation, the
1) In order to closure, the 17 th beam is not changed;

2) Raise the shuttering elevation of the 16 th beam segment to $8 \mathrm{~mm}$.

At the time of closure, altitude difference is $15 \mathrm{~mm}$ between west of final closure and side span,altitude difference is $16 \mathrm{~mm}$ in East side. However, based on $0.78 \%$ design data, the theoretical height difference should be $15.6 \mathrm{~mm}$, then successfully complete the bridge construction. The table 6 can be show that the calculation of completed bridge after the adjustment of elevation of the formwork.

Table 6 Calculation result of completed bridge Linetype

\begin{tabular}{|c|c|c|c|c|c|c|c|c|}
\hline \multirow[b]{2}{*}{$\begin{array}{l}\text { Beam } \\
\text { section } \\
\text { number }\end{array}$} & \multirow[b]{2}{*}{$\begin{array}{c}\text { Shutteri } \\
\text { ng } \\
\text { elevatio } \\
\mathrm{n} / \mathrm{m}\end{array}$} & \multicolumn{3}{|c|}{ Deflection at the stage of pouring } & \multicolumn{4}{|c|}{ Difference analysis with design } \\
\hline & & $\begin{array}{c}\text { Placing } \\
\text { concrete to } \\
\text { make the front } \\
\text { of the casting } \\
\text { beam } \\
\text { downwarping/ } \\
\text { mm }\end{array}$ & $\begin{array}{l}\text { The hanging } \\
\text { basket } \\
\text { produces a } \\
\text { downwarping/ } \\
\text { mm }\end{array}$ & $\begin{array}{c}\text { Finished } \\
\text { bridge } \\
\text { elevation/ } \\
\mathrm{m}\end{array}$ & $\begin{array}{c}\text { Design } \\
\text { elevation/ } \\
\mathrm{m}\end{array}$ & $\begin{array}{c}\text { Altitude } \\
\text { differenc } \\
\mathrm{e} \\
\text { between } \\
\text { Design } \\
\text { elevation } \\
\text { and } \\
\text { bottom of } \\
\text { beam }\end{array}$ & $\begin{array}{l}\text { The } \\
\text { difference } \\
\text { between the } \\
\text { predicted } \\
\text { primary } \\
\text { bridge and } \\
\text { the design } \\
\text { elevation }\end{array}$ & $\begin{array}{c}\text { Elevati } \\
\text { on at } \\
\text { closure/ } \\
\mathrm{m}\end{array}$ \\
\hline $\begin{array}{l}\text { West } \\
17 \text { th }\end{array}$ & 451.893 & -103 & -30 & 451.735 & 454.425 & 2.69 & 0 & 451.715 \\
\hline $\begin{array}{l}\text { West } \\
16 \text { th }\end{array}$ & 451.824 & -93 & -30 & 451.709 & 454.399 & 2.69 & 0 & 451.688 \\
\hline $\begin{array}{l}\text { East } \\
16 \text { th }\end{array}$ & 450.802 & -93 & -30 & 450.687 & 453.377 & 2.69 & 0 & 450.666 \\
\hline $\begin{array}{l}\text { East } \\
17 \text { th }\end{array}$ & 450.809 & -103 & -30 & 450.651 & 453.341 & 2.69 & 0 & 450.631 \\
\hline
\end{tabular}

Note: The design elevation is the elevation value of the construction drawing + aftershrinkage creep + Live load displacement $/ 2$

\section{Conclusion}

Through the calculation of the stress of the main girder and the cable force at each stage of construction and the calculation results of the elevation of the vertical mold, it can be seen that the bridge is in a safe state after the adjustment of the formwork.

1) The stress of the adjusted formwork is within the safe range, and the bearing capacity meets the requirement during the maximum cantilever stage, and the bridge is in a safe state.
2) The calculation result of cable force satisfies the requirement that the safety factor of stay cable is more than 2.

3) After adjustment, there is a small gap between the cable forces, and the maximum gap is 88ton in cable 10th. Compared with the original model, the difference of $2.4 \%$ does not affect the carrying capacity of the bridge.

4) After adjusting the elevation of the formwork of the beam section, the finished bridge shall conform to the design line according to the changed working procedure. 
1. JTG/T D65-1-2007.Guidelines for Design of Highway Cable-Stayed Bridge [S].

2. JTG F80/1-2004.Standard for quality inspection and assessment of highway engineering[S].

3. Shi Jun,Zhao Yue. Closure Technology of Huiqing Yellow River Bridge[J]. Construction Technology.2011(05):44-48.

4. WEI Zuo-ming,MENG Fang-cheng,CHEN Wen. Linear Sensitivity Analysis at Construction Phase of Extradossed Cab1e-stayed Bridge[J]. Western China communication Science and Technology.Bridge and Tunnel engineering.2014(06):65-68.

5. ZHAO Fu-xing. The analysis and research on construction control of low-pylon cable-stayed bridge[J]. HeiLongJiang jiaotong keji.2016(02):80-81.

6. Sun Fuyang. Construction Monitoring of Asymmetric Extradosed Railway Cable-stayed Bridge Tower Beam [J].Railway Construction Technology 2016 (04):15-19.

7. Ming Yuan,Dong Huang Yan. Optimization on Closure Scheme of Multi-Span Prestressed Concrete Box-Girder Bridge[J]. Advanced Materials Research,2011,1067(163).

8. Zhan Yong Yao,Xiao Meng Zhang,Shuai Li,Lian Fu Li,Xiang Hong Pan,Kai Yao. Influence of Closure Sequences on the Rigid Frame-Continuous Girder Bridge Closure[J]. Applied Mechanics and Materials,2013,2547(361).

9. Jun Dong,Tian Liang,Jiang Xiao Feng. Investigation on Optimization of Cable Tension for Extradosed Cable-Stayed Bridge under the Rational Completion Stage $[J]$ Advanced Materials Research,2014,3456(1020).

10. Shao-min Jia. Geometric Closure Control of the Main Channel Girder of Jiaxing-Shaoxing Bridge[J]. Journal of Highway and Transportation Research and Development (English Edition),2015,9(1). 